\title{
Multiple Sclerosis Relapses: Epidemiology, Outcomes and Management. A Systematic Review
}

\author{
Tomas Kalincik \\ Department of Medicine, University of Melbourne; Department of Neurology, Royal Melbourne Hospital, \\ Melbourne, Vic., Australia
}

\section{Key Words}

Multiple sclerosis · Relapse · Therapy · Phenotype ·

Recurrence · Disease outcomes · Steroids - MRI - Registry .

Geography

\begin{abstract}
Relapses (episodic exacerbations of neurological signs or symptoms) are a defining feature of relapsing-remitting multiple sclerosis (MS), the most prevalent MS phenotype. While their diagnostic value relates predominantly to the definition of clinically definite MS, their prognostic value is determined by their relatively high associated risk of incomplete remission resulting in residual disability. The mechanisms governing a relapse incidence are unknown, but numerous modifiers of relapse risk have been described, including demographic and clinical characteristics, many of which represent opportunities for improved disease management. Also relapse phenotypes have been associated with patient and disease characteristics and an individual predisposition to certain phenotypic presentations may imply individual neuroanatomical disease patterns. While immunomodulatory therapies and corticosteroids represent the mainstay of relapse prevention and acute management, respectively, their effect has only been partial and further search for more efficient relapse therapies is warranted. Other areas of research include pathophysiology and determi-
\end{abstract}

nants of relapse incidence, recurrence and phenotypes, including the characteristics of the relapsing and non-relapsing multiple sclerosis variants and their responsiveness to therapies.

(c) 2015 S. Karger AG, Basel

\section{Background}

Episodes of transient exacerbations of neurological disability - known as relapses - are a defining feature of relapsing-remitting multiple sclerosis (MS). From the clinical perspective, relapses represent an essential element in the diagnostics of relapse-onset MS [1]. From the societal perspective, they result in increased consumption of healthcare resources and incur significant costs [2-5].

Relapses represent clinical correlates of impaired axonal conductivity triggered by flair-ups of localised autoimmune process within the CNS (for detailed reviews of immunology and pathology of MS relapses see $[6,7]$ ). Loss of myelin, which is the target of MS autoimmune attack, results in increased electrical capacitance of axons, and is considered to be the primary pathophysiological mechanism of the conduction block [8]. In addition, several substances involved in the MS autoimmune cascade were shown to interfere directly with axonal conductivity. These comprise pro-inflammatory cytokines (such as 
interferon $\gamma$, tumour necrosis factor $\alpha$ ) [9], nitric oxide [10] or 'neuroelectric blocking factors' contained within the IgG fraction of serum [11]. In addition to their possible direct interaction with ion channels [12], they may potentially interfere with the mitochondrial function [13] or synaptic transmission [14].

It is of interest that only a proportion of inflammatory CNS events present clinically as MS relapses. In a serial analysis of 3-monthly brain and spinal cord magnetic resonance imaging (MRI), new or contrast-enhancing lesions were observed on 26 of 28 scans coinciding with relapses (sensitivity 93\%) but also on 19 of 51 scans with no coincident relapses (63\% specificity) [15]. Interestingly, the load of the enhancing lesions was markedly larger among the patients presenting with relapses than those with only subclinical MRI activity [16]. It can be speculated that several factors, including lesion topography, size, time since demyelination and magnitude of the myelin loss determine the clinical phenotype and severity of relapses $[8,17]$.

Changes in relapse-related outcomes have been used as the primary endpoint in the majority of pivotal randomised phase III trials of MS disease-modifying therapies [18]. While relapse activity has been proposed as a marker of treatment response, its relationship to longterm disability outcomes has been a subject of ongoing debate [19]. The purpose of this systematic review is to summarise the published literature concerning relapses - their epidemiology, determinants, diagnostic and prognostic value, clinical outcomes and management with the emphasis on the increasing volume of literature published over the recent four years.

\section{Review Criteria}

References for this review were identified using an electronic database of peer-reviewed literature (PubMed), following a pre-specified review protocol. The search included the terms 'multiple sclerosis' in combination with 'relapse', 'exacerbation', 'attack' or 'bout' within the article title or abstract, published between 1970 and 2014 (the latter two terms were added to the search protocol in response to suggestions from the reviewers). After removing duplicate records, the reference list was hand-searched to identify potentially relevant studies. The abstracts were read and evaluated with respect to the predefined inclusion criteria: studies done in patients with MS or clinically isolated syndrome (CIS), reporting original data, meta-analysis or systematic review of literature, with the primary focus on the epidemiology, prognostics or management of MS relapses, containing sufficient information to evaluate the quality of presented evidence, and published in English. Case reports were not reviewed. The quality assessment evaluated population description and representativeness, control of bias (at the outcome level) and generalizability of the results. The articles selected based on their abstracts were reviewed in full, and relevant information was extracted to be used in the synthesis. Figure 1 represents the PRISMA flow diagram of the reviewed literature.

\section{Epidemiology of MS Relapses}

In their review of relapse incidence in placebo arms from 32 randomised clinical trials published between 1980 and 2008, Inusah and colleagues summarised the reported annualised relapse rates, which ranged from 0.27 to 1.66 relapses per year. The review indicated that the annualised relapse rate has been showing a sustained decline, with the magnitude of this change being 0.36 relapses per 10 years [20]. While this may reflect a longterm decreasing trend in the incidence of relapses among the treatment-naïve patient population, it is more likely that the observed decline is determined by changing criteria of patient inclusion in randomised clinical trials. Due to ethical restraints, an increasingly greater proportion of patients with active disease have been likely to be treated with high-efficacy medication, thus biasing randomised trials to preferentially include patients with relatively less active disease. Additional contributing factors are the increasing baseline patient age and MS duration, and the Will Rogers phenomenon [21, 22]. The decreasing baseline relapse activity and the increasing homogeneity of the trial cohorts may lead to an inflation of relative treatment effects. Attrition bias is an additional source of confounding, introduced by selective withdrawal of patients with on-study MS activity from clinical trials [21]. It can be eliminated by modelling the time to first on-trial relapse [23]. All the above long-term trends need to be considered and accounted for in the design of meta-analyses, which compare outcomes of trials conducted at various points in time.

Seasonal variation in the incidence of MS relapses, with the incidence peak in spring and trough in winter, was demonstrated in a meta-analysis of nine reports of relapse incidence in the northern hemisphere [24]. This observation was confirmed and extended by a large multicentric observational study from the MSBase cohort, 
Fig. 1. PRISMA flow diagram of the reviewed literature.

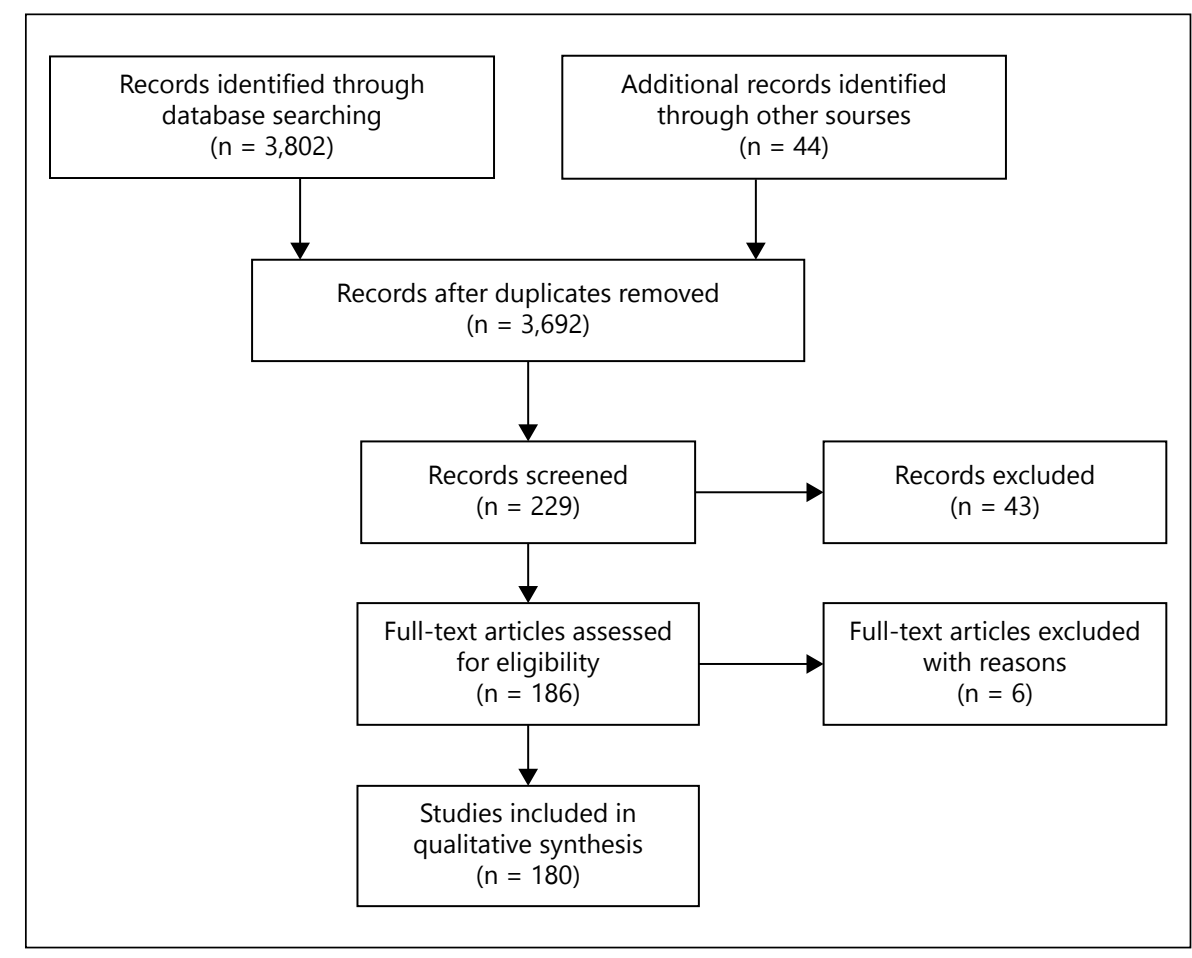

which showed consistent trends in both northern and southern hemispheres [25]. Interestingly, the lag between seasonal ultraviolet radiation trough levels in midwinter and subsequent peak in relapse probability was inversely associated with the latitude (mean of 28.5 days per $10^{\circ}$ of latitude). The observed mean lag was approximately 5 months in Melbourne (37.8 of latitude) and 3 months in Montreal ( $45.5^{\circ}$ of latitude). Studies from several smaller patient cohorts showed variable results, some reporting a spring [26] and other earlier works reporting a summer peak $[27,28]$ of relapse incidence (table 1 ). A hypothesis was proposed that the seasonality of the peak relapse incidence may show a long-term trend towards phaseshift [29], but this view requires further validation.

\section{Individual Risk Factors and Predictors}

A popular hypothesis, which may partially explain the seasonal variation of relapses (see above), indicates an association between the seasonality of relapse incidence and serum levels of 25-hydroxyvitamin D [30-33]. An increment in vitamin $\mathrm{D}$ concentration by $10 \mathrm{nmol} / \mathrm{l}$ was associated with reduced hazard of relapses by $9 \%$ in adults [34], and 34\% in paediatric-onset MS [35]. Similarly, reduction in the hazard of new T2 brain lesions by $15 \%$ and of contrast-enhancing brain lesions by $32 \%$ per each $10 \mathrm{nmol} / \mathrm{l}$ of vitamin D concentration was reported [36]. In addition, serum levels below $50 \mathrm{nmol} / \mathrm{l}$ were associated with a decreased hazard of progression of neurological disability [37]. It is therefore not surprising that vitamin $\mathrm{D}$ supplementation has been suggested as an intervention aimed at decreasing the risk of relapses [38, 39], a hypothesis that is currently being evaluated in four randomised interventional trials in patients with MS or CIS (PrevANZ, VIDAMS, SOLAR, D-Lay-MS) [40, 41], with the additional aim of defining optimal serum vitamin $\mathrm{D}$ levels for reducing clinical MS activity.

A number of previous studies, including large cohort studies and a meta-analysis of 33 observational studies of patients with CIS consistently showed that females are more likely to experience relapses throughout the course of the disease [42-44] (table 1). Relapse incidence is known to decrease with time, represented either by patient age or by MS duration [20,42,44-48]. In a direct comparison of the effects of these largely collinear determinants of relapse frequency, we showed that older age is relatively more closely associated with decline in relapse activity than MS duration [42]. Interestingly, our study suggested that an interaction between sex- and time-dependent changes in relapse frequency may exist, with the attenuation of relapse activity delayed in females com- 
Table 1. Factors predisposing to MS relapses

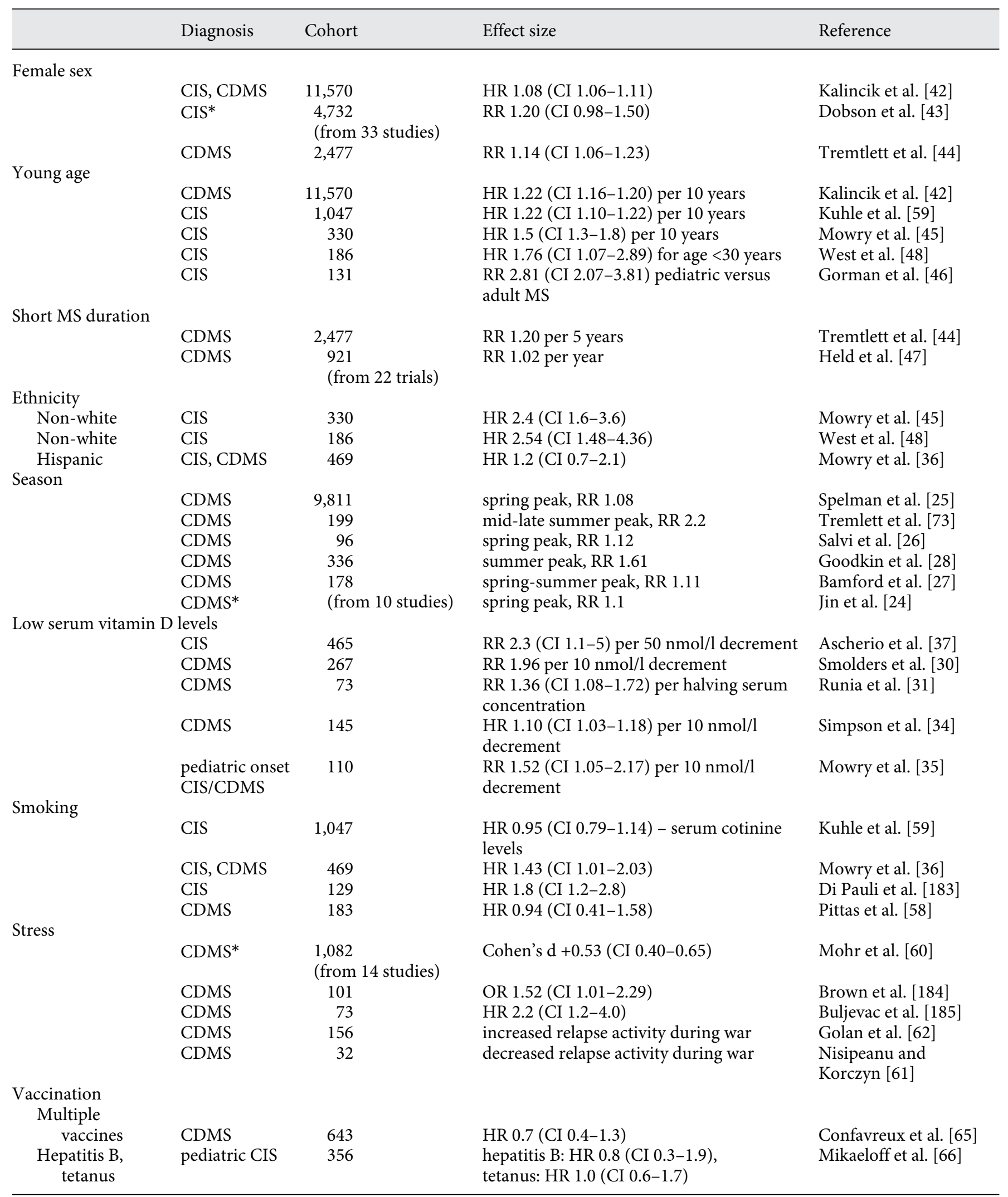


Table 1. (continued)

\begin{tabular}{|c|c|c|c|c|}
\hline Influenza, H1N1 & CDMS (RCT) & 61 & incidence: vaccination $12 \%$ vs. placebo $14 \%$ & Bamford et al. [67] \\
\hline Influenza, H1N1 & CDMS (RCT) & 88 & incidence: vaccination $3 \%$ vs. placebo $6.5 \%$ & Myers et al. [68] \\
\hline Yellow fever & CDMS & 7 & RR 12.8 (CI 4.3-38) & Farez et al. [69] \\
\hline \multicolumn{5}{|l|}{ Infections } \\
\hline $\begin{array}{c}\text { Influenza A, } \\
\text { EBV }\end{array}$ & CDMS & 407 & $\begin{array}{l}\text { influenza A: OR } 6.5 \text { (CI 1.8-24), } \\
\text { EBV: OR } 4.4 \text { (CI 1.3-15) }\end{array}$ & Oikonen et al. [186] \\
\hline Chlamydia & CDMS & 73 & RR 3.1 (CI 1.3-6.7) & Buljevac et al. [71] \\
\hline URTI & CDMS & 41 & RR 2.0 (CI $1.3-3.2)$ & Edwards et al. [72] \\
\hline \multirow{3}{*}{ URTI } & CDMS & 199 & $\mathrm{r}$ (Pearson) 0.39 & Tremlett et al. [73] \\
\hline & CDMS & 170 & RR 2.8 & Sibley et al. [74] \\
\hline & CDMS & 60 & RR 1.3 & Andersen et al. [75] \\
\hline \multicolumn{5}{|l|}{ Pregnancy } \\
\hline & CDMS & $\begin{array}{l}33 \\
\text { (49 pregnancies) }\end{array}$ & postpartum RR 1.6 & Roullet et al. [187] \\
\hline & CDMS & (191 pregnancies) & postpartum versus pregnancy RR 3.4 & Nelson et al. [79] \\
\hline & CDMS & $\begin{array}{l}70 \\
\text { (98 pregnancies) }\end{array}$ & $\begin{array}{l}\text { pregnancy RR } 0.6 \text {; postpartum RR not } \\
\text { significant }\end{array}$ & Salemi et al. [80] \\
\hline \multicolumn{5}{|c|}{ Assisted reproduction } \\
\hline & CDMS & $\begin{array}{l}32 \\
\text { (70 IVF cycles) }\end{array}$ & RR 2.0 & Michel et al. [90] \\
\hline & CDMS & $\begin{array}{l}16 \\
\text { (26 IVF cycles) }\end{array}$ & RR 6.9 (CI 3.4-14) & Correale et al. [93] \\
\hline
\end{tabular}

* Meta-analysis. CI = Confidence interval; CIS = clinically isolated syndrome; CDMS = clinically definite multiple sclerosis; EBV = Epstein-Barr virus; $\mathrm{HR}$ = hazard ratio; $\mathrm{MS}=$ multiple sclerosis; $\mathrm{OR}=$ odds ratio; $\mathrm{RCT}$ = randomised clinical trial; $\mathrm{RR}=$ rate ratio; $\mathrm{URTI}=$ upper respiratory tract infection.

pared to males. In addition to sex and age, non-white ethnicity was associated with a relatively increased risk of relapse in patients with CIS $[45,48]$.

Pooled data from the placebo arms of 22 randomised trials demonstrated that pre-trial relapse activity was strongly associated with on-trial relapse incidence [47]. This suggests that the level of relapse activity is in part individually determined. However, the existence of genetic determinants of relapse frequency has not been proven as yet. It was previously reported that the major histocompatibility locus that has the strongest association with susceptibility to MS, HLA-DRB1*1501, may also be associated with the probability of conversion to definite MS in patients with a CIS [49]. In another study, three susceptibility loci were associated with relapse severity: MPHOSPH9 positively, and RGS1 and TNFRSF1A negatively [50]. In contrast, other studies did not find any associations between the relapse hazard and the known loci of MS susceptibility [51-53]. Moreover, the HLA-DRB1 polymorphism was not found to be associated with the relapsing- vs. progressive-onset MS course [54-57].

In addition to the above non-modifiable risk factors, many modifiable relapse risk factors are known. A large cohort study demonstrated positive association between smoking and the increased relapse risk in patients with definite relapsing-remitting MS as well as clinically isolated syndrome, an observation that was also supported by the greater risk of developing new hyperintense 
T2 lesions [36]. Moreover, smokers with CIS are at greater risk of conversion to clinically definite MS through experiencing further relapses [48]. In contrast, two other studies did not find any association between smoking status [58] and serum cotinine concentration [59] and the relapse hazard but the former study showed a quantitative association of smoking with disability accrual. It is generally believed by patients and physicians that stress may potentiate disease reactivation presenting with a clinical relapse. A meta-analysis of 14 studies showed that a positive association between non-traumatic stressful life events and the incidence of relapses is consistently supported by literature [60]. The magnitude of this pooled effect even exceeded the observed effect of treatment with interferon $\beta$ (Cohen's $d=0.56$ vs. 0.36 , respectively). A question was raised whether the quality of the stressor may modulate this relationship. Two studies that examined relapse rates in patients exposed to the threat of missile attacks in war arrived at contrasting conclusions [61, $62]$. Interestingly, there was no indication of an association between relapses and physical trauma [63]. A more detailed discussion of the impact of stress on MS activity is provided in a review by Artemiadis and colleagues [64]. The majority of studies investigating relapse incidence in patients undergoing vaccinations against influenza (including the H1N1 subtype), hepatitis B and tetanus did not demonstrate any associations [65-68]. The relationship between attenuated vaccines (such as the vaccine against yellow fever) and relapse risk warrants further investigation [69]. Episodes of infectious diseases were invariably associated with higher risk of relapses [70-75]. An association of pregnancy with relapse frequency was noted by Millar and colleagues already in 1959 [76]. Later, a number of studies demonstrated decreased risk of relapses during pregnancy, in particular during its third trimester [77-85]. However, the relatively lower risk of relapses is outweighed by the markedly increased relapse activity during the first post-partum trimester, observed in most of these studies. These observations have led to an ongoing discussion concerning optimal post-partum management, with some authors advocating early postpartum resumption of immunomodulatory therapy [86]. Some studies suggested that the effect of breastfeeding was protective; however, these studies were vulnerable to confounding with the provided evidence being inconclusive and warranting further confirmation [79, 85, 87-89]. Women undergoing an assisted reproductive technique are exposed to additional risks of experiencing increased disease activity, presumably in association with the hormonal stimulation procedures [90-93]. The quantitative changes in the immune system associated with hormonal stimulation were in keeping with the changes induced by the gonadotropin releasing hormone [93], and some studies proposed that higher relapse risk may be triggered selectively by gonadotropin-releasing hormone agonists but not antagonists $[90,91]$.

A number of other factors were proposed as potential modifiers of the risk of MS episodic activity, including poor ambient air quality $[94,95]$, however, most of these are based on anecdotal evidence and therefore warrant further investigation.

Discontinuation of highly effective therapy, in particular natalizumab, was reported to lead to clinical reactivation of MS [96-99], with $27 \%$ of patients experiencing relapses during the time between discontinuing natalizumab and initiating subsequent immunomodulatory therapy (i.e. the 'wash-out' period) $[98,100]$. The control of disease activity was improved by switching to another highly active therapy, namely fingolimod, and further amelioration of the post-switch relapse activity was achieved by minimising the duration of the wash-out pe$\operatorname{riod}[98,101]$.

\section{Relapse Phenotype}

The initial presentation suggestive of MS is most commonly associated with visual, motor or sensory features. Cossburn and colleagues reported a study in a population-based cohort of 1,424 patients with the following proportions of the initial events: visual $18 \%$, long tractrelated $47 \%$, cerebellar $10 \%$, brainstem $10 \%$, cerebral $1 \%$ and polyregional $11 \%$ [102]. An analysis from 14,969 patients from the MSBase cohort showed a similar distribution of the initial presenting clinical features: visual $27 \%$, pyramidal $22 \%$, sensory $46 \%$, cerebellar $7 \%$, brainstem $20 \%$, sphincteric $3 \%$ and cognitive $1.4 \%$ [103]. In a study of 105 patients with pediatric MS, the initial clinical attacks involved visual system in $25 \%$, spinal cord in $36 \%$, brainstem or cerebellum in $51 \%$, and cerebrum in $9 \%$ of the reported events [104]. It is noteworthy that the proportions of relapse phenotypes change with time, either expressed as patient age or the time from the first MS clinical presentation. While the relative incidence of visual, sensory and brainstem relapses declines with time, pyramidal (in particular concerning the lower limbs), sphincteric and cerebellar relapses become more frequent later in the disease course or in older patients $[102,103]$. Moreover, severe relapses are more commonly observed among young patients $[105,106]$. These data confirm the 
experience of many clinicians and patients that MS-related symptomatology tends to follow time-dependent patterns. The mechanisms underlying this shift in functional (and, presumably, topographic) susceptibility to relapses remain to be explained.

In addition to the effect of time, sex may contribute to the phenotypic patterns of MS relapses. We showed that women tend to present with visual and sensory relapses more frequently than men, who are relatively more likely to present with pyramidal, brainstem and cerebellar relapses [103].

It is of interest that patients tend to experience relapses, which are phenotypically similar to their preceding clinical episodes $[103,107,108]$. This 'phenotypic relapse recurrence' could potentially be attributed to individual patterns of structural CNS damage. In fact, studies showed that areas of demyelination are commonly localised within previously remyelinated regions $[109,110]$. This inherent predisposition is likely to be determined by numerous polygenic factors, including genetic factors, such as some of the MS susceptibility factors [111], several genes involved in the regulation of immune cell function, myelin and neural growth [112], and genetically correlated CD4 T-cell immunoreactivity [113].

\section{Prognostic Value of Relapses}

While a debate may exist about the significance of MS relapses $[19,114,115]$, a positive relationship between relapses and the accumulation of permanent neurological disability was demonstrated. It was shown that incomplete recovery follows a marked proportion of relapses, with $42-49 \%$ of relapses resulting in a residual increase in Expanded Disability Status Scale (EDSS) by at least 0.5 steps and $28-33 \%$ of relapses leading to a 1-step EDSS accrual $[116,117]$. In particular, the accumulation of disability is correlated with the level of relapse activity within the initial 2-5 years after the first clinical presentation of MS [118-121] and it was suggested that the impact of relapses on long-term disease outcomes decreases thereafter [122].

Besides relapse frequency, the long-term disability accrual is also associated with relapse phenotype. Several studies identified attacks (i.e. relapses or the initial clinical events) with the impact on sphincteric [123-127] or pyramidal function $[124,126,128]$ as being predictive of poorer long-term disability outcomes, while the cerebellar and brainstem attacks showed mixed results (for review, see [129]). In contrast, attacks with the features of optic neuritis were associated with relatively more favourable disability outcomes $[127,128,130]$. This is in keeping with our study in which sensory, visual and brainstem relapses were relatively more likely to result in complete recovery compared to pyramidal, sphincteric, cognitive and cerebellar relapses [103].

It is of interest that while women tend to present with more frequent relapses (see above), males are predisposed to poorer long-term disability outcomes $[120,121,123$, 125]. This seemingly paradoxical phenomenon could be explained by the differential effect of various relapse phenotypes on the long-term disability accrual. While men are more likely to develop pyramidal, cerebellar and brainstem relapses, of which pyramidal and cerebellar relapses pose a relatively higher risk of incomplete remission, women are more prone to visual and sensory relapses, which are relatively more likely to recover completely [103]. In fact, relapse recovery was shown to be negatively associated with the male gender. A similar association was reported for older age, progressive MS course and relapse severity $[48,102,103,105,127]$. These associations could be mediated through a number of mechanisms related to sex, age or lesion location, such as variations in susceptibility to inflammatory damage, structural changes underlying relapses and synaptic plasticity $[131,132]$.

Persistent impairment of a certain neurological function is commonly preceded by relapses of similar phenotype, with the visual and sensory pathways being relatively more susceptible to recurrent damage than the pyramidal and cerebellar pathways [133]. In addition, relapse severity and the subsequent recovery tend be individually specific [106]. These observations are reminiscent of the phenotypic relapse recurrence discussed earlier and suggest that the phenotypic presentations of relapses as well as the subsequent accumulation of permanent neurological disability, including its phenotype and trajectory, constitute disease features with a high degree of individual specificity.

\section{Relapses and the Diagnosis of MS}

Besides their importance as a marker of disease activity and their association with irreversible neurological impairment, MS relapses are a defining feature of relapsing MS and are therefore an important diagnostic marker. Clinical dissemination in time (i.e. incidence of at least two MS-related attacks) has been a crucial element of the MS diagnostic criteria [1] and in numerous jurisdictions 


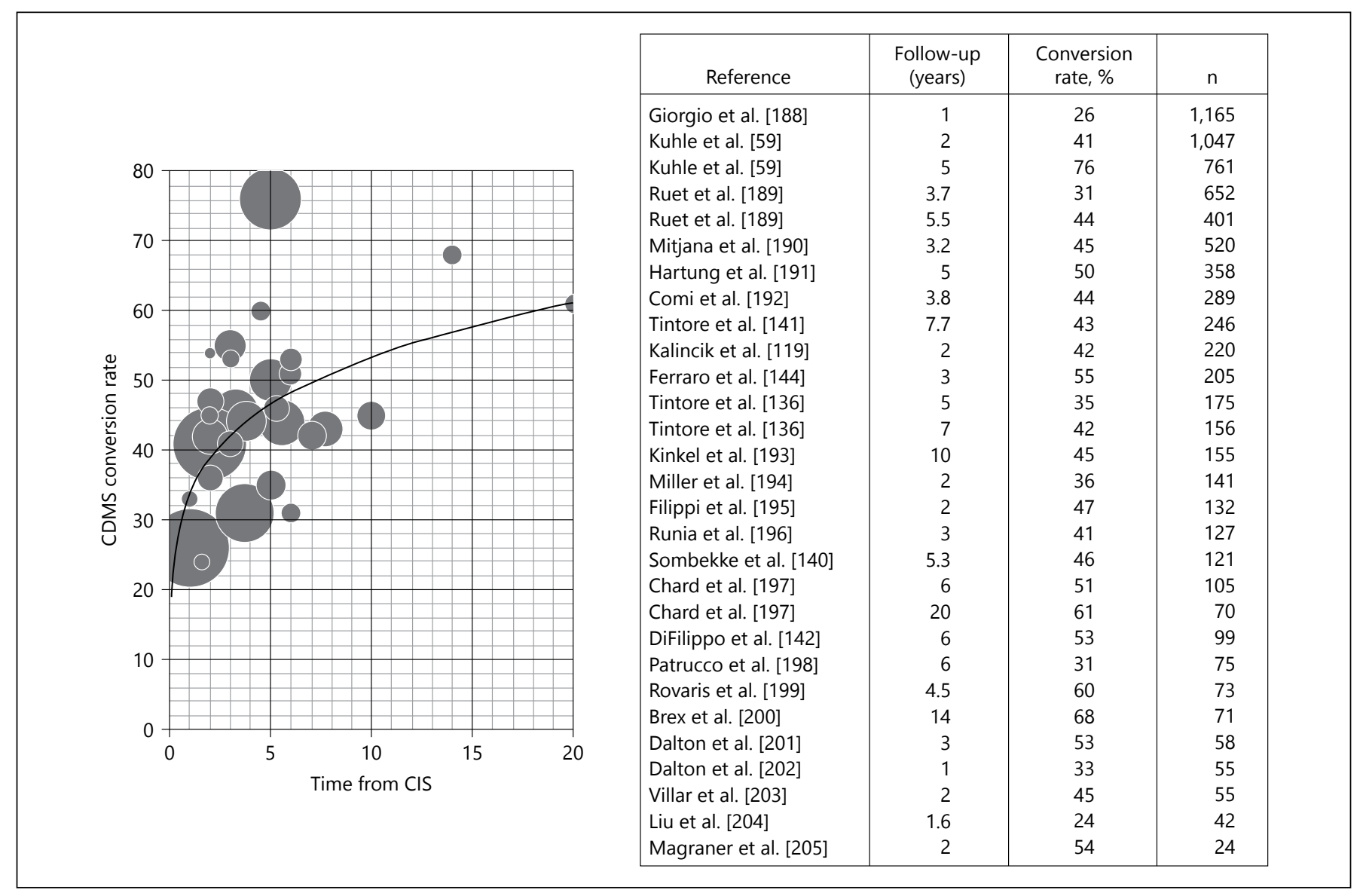

Fig. 2. Probability of conversion to clinically definite MS. The rate of conversion from CIS to clinically definite multiple sclerosis (CDMS) as reported in previously published studies. A marked variance in the clinical and radiologic inclusion criteria and therapy exists among the studies.

has been a requisite of disease-modifying therapy. Therefore, the occurrence of a second attack, marking the conversion from CIS to clinically definite MS, has received considerable attention in the literature (fig. 2). The average estimated cumulative probability of experiencing a second, diagnostic clinical attack is about $40 \%$ at 2 years from the onset of the initial presenting symptom. Thereafter, the increment in the cumulative probability of a relapse slows, with the estimated risk at 5 years from CIS being $47 \%$. It should be noted that these estimates were derived from multiple studies with a great variability in the definition of CIS. The clinical and paraclinical phenotype at the time of the first clinical presentation may markedly influence the probability of a second attack.

Phenotype of the first clinical presentation suggestive of MS has long been used by clinicians as an empirical estimator of the risk of conversion to clinically definite MS (for review see [134]). This risk is further modified by surrogate (paraclinical) markers. Patients with abnormal MRI appearance at the time of CIS are at a significantly higher risk of conversion to clinically definite MS [135139]. In a multicentric study of 1,047 patients, the conversion rates for those with $0-1,2-9$ and more than 9 hyperintense T2 lesions were $15 \%, 40 \%$ and $52 \%$ at 2 years and $55 \%, 75 \%$ and $83 \%$ at 5 years, respectively [59]. In another study among 175 patients, the conversion rates over the median of 7 years were $9 \%$ for those with normal MRI, $44 \%$ for those fulfilling 1-2 Barkhof criteria (hazard ratio 6.1 ) and $61 \%$ for those fulfilling 3-4 Barkhof criteria (hazard ratio 17) at the time of the first clinical event [136]. The location of the hyperintense T2 lesions further increases the predictive value of MRI, with brainstem and spinal cord lesions heralding a relatively higher risk of further demyelinating activity [140, 141]. Moreover, quantitative changes, presenting as accelerated global or regional brain atrophy contribute to the prediction of the 
second attack [119, 137, 142, 143]. Laboratory analysis of cerebrospinal fluid is another commonly used paraclinical tool. The presence of cerebrospinal fluid-specific oligoclonal bands at the time of the CIS is associated with increased odds of the second attack (the reported odds ratios range between 1.7 and 4.7) [59, 144-146].

\section{Management and Prevention of Relapses}

Treatment with high-dose corticosteroids has been the mainstay of acute therapy of MS relapses. A meta-analysis of 3 studies reported a significant effect of high-dose methylprednisolone on the recovery of relapse-associated disability (difference of EDSS scores $0.76,95 \%$ confidence interval $0.50-1.02$, over 5-7 days compared to placebo) [147]. In addition, a study of acute optic neuritis showed an effect of intravenous methylprednisolone but not of oral prednisone on the recovery of visual function [148]. This phenomenon appears to be determined by the dose rather than the route of administration, as another three studies showed that the effect of high-dose oral methylprednisolone on relapse recovery was comparable to that of methylprednisolone administered intravenously [149-152] and that the effect of methylprednisolone was dose-dependent [153]. A substantially more expensive treatment option is adrenocorticotropic hormone. Its immunomodulatory effect is mediated through the stimulation of endogenous steroid production, but a contribution of direct modulation of the NF- $\kappa B$ signalling pathway by the melanocortin system was also implied [154] (for review see [155]). Two early studies comparing intravenous methylprednisolone and adrenocorticotropic hormone reported similar efficacies of both therapeutic regimens, but implied a relatively more prompt effect of high-dose corticosteroids $[156,157]$. Two randomised, double-blind trials showed non-inferiority of either of the two therapies $[158,159]$. A meta-analysis of six studies confirmed the effect of both therapies on relapse recovery (odds ratio $0.37,95 \%$ confidence interval 0.24-0.57), with a statistically non-significant trend towards a more pronounced recovery after treatment with methylprednisolone [160]. In addition, plasma exchange and intravenous immunoglobulins have occasionally been used to facilitate post-relapse remission; however, consistent evidence of their effect has been lacking $[161,162]$. For a more detailed overview of acute therapy of MS relapses see [163].

A large body of evidence obtained from randomised clinical trials showed the effect of the currently used immunomodulatory therapies on decreasing the hazard of relapses (by 36-85\%, depending on the agent) in patients with relapsing-remitting MS [18]. In fact, the majority of the pivotal trials used the effect on relapse incidence as their primary outcome and the evaluated therapies have been approved mostly for the prevention of relapses. However, some evidence from the clinical trials [164166] as well as from observational studies is strongly suggestive of the positive effect of these medications also on disability outcomes [167-170]. A meta-analysis of 40 randomised clinical trials of disease-modifying therapies in MS suggested that treatment-related attenuation of relapse activity is positively associated with improved disability outcomes [171].

Relapse activity also carries important prognostic information about the predicted effect of disease modifying therapy. Patients with a high relapse rate prior to or shortly after initiating disease modifying therapy are more likely to suffer from ongoing relapses despite continued treatment compared with those with low pre-treatment relapse activity or good early response to therapy $[47,101$, 172-174]. This may seem to be in contrast with the fact that while the effect of the available immunomodulatory therapies has been demonstrated in relapsing-remitting MS, compelling evidence for its effect in progressive-onset MS has been lacking. Therefore, a certain minimum relapse activity, sufficient to define the disease as relapsing-remitting, is instrumental in determining the treatment-responsive MS phenotype. An excellent example is provided by chemotherapy followed by salvage haematopoetic stem cell transplantation, which was suggested to ameliorate disease activity only in patients with relapsing-remitting but not progressive MS course [175-177].

\section{Patient Perspective}

It is the experience of many patients and their physicians that comprehensive evaluation of symptoms within the limited scope of routine clinical appointments is challenging. Therefore, on many occasions relapse-related symptoms may remain unnoticed or unaddressed [178]. While validated scales are commonly used to evaluate the various aspects of MS-related disability (e.g. EDSS, MS Functional Composite, Minimal Assessment of Cognitive Function in MS), specialised screening tools aiming at evaluation of relapses are scarce. In this context, screening questionnaires aimed at the identification of patient-reported symptoms (such as the Assessing Relapse in Multiple Sclerosis questionnaire) hold the potential to improve recognition of relapses in routine clinical care [179]. 
In addition to screening for the symptoms of potential relapses, such questionnaires enable better evaluation of MS burden from the patient perspective. A web-based self-report study showed that MS relapses are associated with significant decline in the quality of life, functional ability and increased costs to the patients [180]. Another study assessing patient-reported outcomes, including several physical and mental health scales, indicated that patients experienced decreased quality of life over one year following relapses [181]. The effect of acute therapy on the subjective recovery from relapses was also studied. In a study of patient-reported data from the North American Research Committee on Multiple Sclerosis (NARCOMS) registry, patients indicated a relatively better recovery from relapses when treated with intravenous or oral corticosteroids in comparison to no treatment [182]. However, a sizeable proportion of patients felt that the steroid therapy did not result in complete resolution of the relapse-related symptoms (32 and 34\%, respectively). This is in keeping with the conclusions of the randomised clinical trials of relapse therapies (see above) and provides additional evidence supporting the role of the disease-modifying therapy in the management of MS.

\section{Summary}

Relapses of MS activity represent a significant physical, emotional and economic burden to both patients and society. Their incidence is influenced by numerous factors, including patient sex, age, disease duration, ethnic- ity, season, latitude, serum vitamin D levels, smoking, stress, infectious diseases, pregnancy, and assisted reproduction. Importantly, many of these risk factors are modifiable and as such deserve appropriate attention in the process of maximising favourable MS outcomes. Neither the mechanisms governing the relapse patterns associated with patient sex, age or disease duration, nor individual predisposition to relapse frequency, phenotype, severity, and recovery have so far been deciphered. These represent questions with the potential to cast light onto the pathophysiology of relapsing-remitting MS. Despite the proven effect of acute relapse therapy, a large proportion of relapses leads to the accumulation of residual disability. Therefore, the prevention of relapses represents an important goal of disease-modifying therapy, with the potential for a marked impact on the accumulation of permanent neurological disability.

\section{Acknowledgements}

The author wishes to thank Emeritus Professor Phil Waite who assisted in the proof-reading of the manuscript.

\section{Conflict of Interests Statement}

Tomas Kalincik received research support from National Health and Medical Research Council (fellowship 1071124, project grant 1083539), Multiple Sclerosis Research Australia (fellowship 11-054) and University of Melbourne, and conference travel support and consultancy/speaker honoraria from Genzyme, Novartis, Biogen Idec, Sanofi Aventis, Teva, BioCSL and Merck Serono.

\section{References}

1 Polman CH, Reingold SC, Banwell B, Clanet M, Cohen JA, Filippi M, Fujihara K, Havrdova $\mathrm{E}$, Hutchinson $\mathrm{M}$, Kappos L, Lublin FD, Montalban X, O'Connor P, Sandberg-Wollheim M, Thompson AJ, Waubant E, Weinshenker B, Wolinsky JS: Diagnostic criteria for multiple sclerosis: 2010 revisions to the McDonald criteria. Ann Neurol 2011;69:292302.

2 Raimundo K, Tian H, Zhou H, Zhang X, Kahler KH, Agashivala N, Kim E: Resource utilization, costs and treatment patterns of switching and discontinuing treatment of $\mathrm{ms}$ patients with high relapse activity. BMC Health Serv Res 2013;13:131.

3 Blahova Dusankova J, Kalincik T, Dolezal T, Kobelt G, Havrdova E: Cost of multiple sclerosis in the Czech Republic: the COMS study. Mult Scler 2012;18:662-668.
4 O'Brien JA, Ward AJ, Patrick AR, Caro J: Cost of managing an episode of relapse in multiple sclerosis in the United States. BMC Health Serv Res 2003;3:17.

5 Kobelt G, Berg J, Lindgren P, Fredrikson S, Jönsson B: Costs and quality of life of patients with multiple sclerosis in Europe. J Neurol Neurosurg Psychiatry 2006;77:918-926.

6 Steinman L: Immunology of relapse and remission in multiple sclerosis. Annu Rev Immunol 2014;32:257-281.

7 Barnett MH, Henderson AP, Prineas JW: The macrophage in MS: just a scavenger after all? Pathology and pathogenesis of the acute MS lesion. Mult Scler 2006;12:121-132.

8 Smith KJ, McDonald WI: The pathophysiology of multiple sclerosis: the mechanisms underlying the production of symptoms and the natural history of the disease. Philos
Trans R Soc Lond B Biol Sci 1999;354:16491673.

9 Brinkmeier H, Seewald MJ, Wollinsky $\mathrm{KH}$ Rüdel R: On the nature of endogenous antiexcitatory factors in the cerebrospinal fluid of patients with demyelinating neurological disease. Muscle Nerve 1996;19:54-62.

10 Redford EJ, Kapoor R, Smith KJ: Nitric oxide donors reversibly block axonal conduction: demyelinated axons are especially susceptible. Brain 1997;120:2149-2157.

11 Schauf CL, Davis FA: The occurrence, specificity, and role of neuroelectric blocking factors in multiple sclerosis. Neurology 1978;28:34-39.

12 Takigawa T, Yasuda H, Kikkawa R, Shigeta Y, Saida T, Kitasato H: Antibodies against GM1 ganglioside affect $\mathrm{K}+$ and $\mathrm{Na}+$ currents in isolated rat myelinated nerve fibers. Ann Neurol 1995;37:436-442. 
13 Bolaños JP, Almeida A, Stewart V, Peuchen S, Land JM, Clark JB, Heales SJ: Nitric oxidemediated mitochondrial damage in the brain: mechanisms and implications for neurodegenerative diseases. J Neurochem 1997;68: 2227-2240.

$14 \mathrm{Yu} \mathrm{B}$, Shinnick-Gallagher P: Interleukin-1 beta inhibits synaptic transmission and induces membrane hyperpolarization in amygdala neurons. J Pharmacol Exp Ther 1994;271:590-600.

15 Wiebe S, Lee DH, Karlik SJ, Hopkins M, Vandervoort MK, Wong CJ, Hewitt L, Rice GP, Ebers GC, Noseworthy JH: Serial cranial and spinal cord magnetic resonance imaging in multiple sclerosis. Ann Neurol 1992;32: 643-650.

16 Gasperini C, Pozzilli C, Bastianello S, Koudriavtseva T, Colleluori A, Millefiorini E, Thompson AJ, Horsfield MA, Galgani S, Bozzao L, Fieschi C: The influence of clinical relapses and steroid therapy on the development of Gd-enhancing lesions: a longitudinal MRI study in relapsing-remitting multiple sclerosis patients. Acta Neurol Scand 1997;95: 201-207.

17 Davis FA: The clinico-radiological paradox in multiple sclerosis: novel implications of lesion size. Mult Scler 2014;20:515-516.

18 Filippini G, Del Giovane C, Vacchi L, D’Amico R, Di Pietrantonj C, Beecher D, Salanti G: Immunomodulators and immunosuppressants for multiple sclerosis: a network meta-analysis. Cochrane Database Syst Rev 2013;6:CD008933.

19 Hutchinson M: Relapses do not matter in relation to long-term disability: commentary. Mult Scler 2011;17:1417.

20 Inusah S, Sormani MP, Cofield SS, Aban IB, Musani SK, Srinivasasainagendra V, Cutter GR: Assessing changes in relapse rates in multiple sclerosis. Mult Scler 2010;16:1414-1421.

21 Steinvorth SM, Rover C, Schneider S, Nicholas R, Straube S, Friede T: Explaining temporal trends in annualised relapse rates in placebo groups of randomised controlled trials in relapsing multiple sclerosis: systematic review and meta-regression. Mult Scler 2013; 19:1580-1586.

22 Sormani MP, Tintorè $M$, Rovaris $M$, Rovira A, Vidal X, Bruzzi P, Filippi M, Montalban X: Will Rogers phenomenon in multiple sclerosis. Ann Neurol 2008;64:428-433.

23 Sormani MP, Signori A, Siri P, De Stefano N: Time to first relapse as an endpoint in multiple sclerosis clinical trials. Mult Scler 2013;19: 466-474.

24 Jin Y, de Pedro-Cuesta J, Söderström M, Stawiarz L, Link H: Seasonal patterns in optic neuritis and multiple sclerosis: a meta-analysis. J Neurol Sci 2000;181:56-64.

25 Spelman T, Gray O, Trojano M, Petersen T, Izquierdo G, Lugaresi A, Hupperts R, Bergamaschi R, Duquette P, Grammond P, Giuliani G, Boz C, Verheul F, Oreja-Guevara C, Barnett M, Grand'Maison F, Edite Rio M, LechnerScott J, Van Pesch V, Fernandez Bolanos R,
Flechter S, Den Braber-Moerland L, Iuliano G, Amato MP, Slee M, Cristiano E, Saladino ML, Paine M, Vella N, Kasa K, Deri N, Herbert J, Moore F, Petkovska-Boskova T, Alroughani R, Savino A, Shaw C, Vucic S, Santiago V, Bacile EA, Skromne E, Poehlau D, Cabrera-Gomez JA, Lucas R, Butzkueven H: Seasonal variation of relapse rate in multiple sclerosis is latitude dependent. Ann Neurol 2014;76:880-890.

26 Salvi F, Bartolomei I, Smolensky MH, Lorusso A, Barbarossa E, Malagoni AM, Zamboni P, Manfredini R: A seasonal periodicity in relapses of multiple sclerosis? A single-center, population-based, preliminary study conducted in Bologna, Italy. BMC Neurol 2010; 10:105.

27 Bamford CR, Sibley WA, Thies C: Seasonal variation of multiple sclerosis exacerbations in Arizona. Neurology 1983;33:697-701.

28 Goodkin DE, Hertsgaard D: Seasonal variation of multiple sclerosis exacerbations in North Dakota. Arch Neurol 1989;46:10151018 .

29 Iuliano G, Boz C, Cristiano E, Duquette P, Lugaresi A, Oreja-Guevara C, Van Pesch V: Historical changes of seasonal differences in the frequency of multiple sclerosis clinical attacks: a multicenter study. J Neurol 2013;260: 1258-1262.

30 Smolders J, Menheere P, Kessels A, Damoiseaux J, Hupperts R: Association of vitamin D metabolite levels with relapse rate and disability in multiple sclerosis. Mult Scler 2008;14: 1220-1224.

31 Runia TF, Hop WC, de Rijke YB, Buljevac D, Hintzen RQ: Lower serum vitamin D levels are associated with a higher relapse risk in multiple sclerosis. Neurology 2012;79:261266.

32 Kampman MT, Brustad M: Vitamin D: a candidate for the environmental effect in multiple sclerosis - observations from Norway. Neuroepidemiology 2008;30:140-146.

33 Martinelli V, Dalla Costa G, Colombo B, Dalla Libera D, Rubinacci A, Filippi M, Furlan R, Comi G: Vitamin D levels and risk of multiple sclerosis in patients with clinically isolated syndromes. Mult Scler 2014;20:147155.

34 Simpson S Jr, Taylor B, Blizzard L, Ponsonby AL, Pittas F, Tremlett H, Dwyer T, Gies P, van der Mei I: Higher 25-hydroxyvitamin D is associated with lower relapse risk in multiple sclerosis. Ann Neurol 2010;68:193-203.

35 Mowry EM, Krupp LB, Milazzo M, Chabas D, Strober JB, Belman AL, McDonald JC, Oksenberg JR, Bacchetti P, Waubant E: Vitamin D status is associated with relapse rate in pediatric-onset multiple sclerosis. Ann Neurol 2010; 67:618-624

36 Mowry EM, Waubant E, McCulloch CE, Okuda DT, Evangelista AA, Lincoln RR, Gourraud PA, Brenneman D, Owen MC, Qualley P, Bucci M, Hauser SL, Pelletier D: Vitamin D status predicts new brain magnetic resonance imaging activity in multiple sclerosis. Ann Neurol 2012;72:234-240.
37 Ascherio A, Munger KL, White R, Köchert K Simon KC, Polman CH, Freedman MS, Hartung HP, Miller DH, Montalbán X, Edan G, Barkhof F, Pleimes D, Radü EW, Sandbrink R, Kappos L, Pohl C: Vitamin D as an early predictor of multiple sclerosis activity and progression. JAMA Neurol 2014;71:306-314.

38 Goldberg P, Fleming MC, Picard EH: Multiple sclerosis: decreased relapse rate through dietary supplementation with calcium, magnesium and vitamin D. Med Hypotheses 1986;21:193-200.

39 Pierrot-Deseilligny C, Rivaud-Péchoux S, Clerson P, de Paz R, Souberbielle JC: Relationship between 25-OH-D serum level and relapse rate in multiple sclerosis patients before and after vitamin D supplementation. Ther Adv Neurol Disord 2012;5:187-198.

40 Bhargava P, Cassard S, Steele SU, Azevedo C, Pelletier D, Sugar EA, Waubant E, Mowry EM: The vitamin $D$ to ameliorate multiple sclerosis (VIDAMS) trial: study design for a multicenter, randomized, doubleblind controlled trial of vitamin D in multiple sclerosis. Contemp Clin Trials 2014;39: 288-293.

41 Smolders J, Hupperts R, Barkhof F, Grimaldi LM, Holmoy T, Killestein J, Rieckmann P, Schluep M, Vieth R, Hostalek U, Ghazi-Visser L, Beelke M; SOLAR Study Group: Efficacy of vitamin D3 as add-on therapy in patients with relapsing-remitting multiple sclerosis receiving subcutaneous interferon $\beta-1 \mathrm{a}$ : a Phase ii, multicenter, double-blind, randomized, placebo-controlled trial. J Neurol Sci 2011;311:44-49.

42 Kalincik T, Vivek V, Jokubaitis V, LechnerScott J, Trojano M, Izquierdo G, Lugaresi A, Grand'maison F, Hupperts R, Oreja-Guevara C, Bergamaschi R, Iuliano G, Alroughani R, Van Pesch V, Amato MP, Slee M, Verheul F, Fernandez-Bolanos R, Fiol M, Spitaleri DL, Cristiano E, Gray O, Cabrera-Gomez JA, Shaygannejad V, Herbert J, Vucic S, Needham M, Petkovska-Boskova T, Sirbu CA, Duquette P, Girard M, Grammond P, Boz C, Giuliani G, Rio ME, Barnett M, Flechter S, Moore F, Singhal B, Bacile EA, Saladino ML, Shaw C, Skromne E, Poehlau D, Vella N, Spelman T, Liew D, Kilpatrick TJ, Butzkueven H; MSBase Study Group: Sex as a determinant of relapse incidence and progressive course of multiple sclerosis. Brain 2013;136:3609-3617.

43 Dobson R, Ramagopalan S, Giovannoni G: The effect of gender in clinically isolated syndrome (CIS): a meta-analysis. Mult Scler 2012;18:600-604.

44 Tremlett H, Zhao Y, Joseph J, Devonshire V; UBCMS Clinic Neurologists: Relapses in multiple sclerosis are age- and time-dependent. J Neurol Neurosurg Psychiatry 2008;79: 1368-1374.

45 Mowry EM, Pesic M, Grimes B, Deen SR, Bacchetti P, Waubant E: Clinical predictors of early second event in patients with clinically isolated syndrome. J Neurol 2009;256:10611066. 
46 Gorman MP, Healy BC, Polgar-Turcsanyi M, Chitnis T: Increased relapse rate in pediatriconset compared with adult-onset multiple sclerosis. Arch Neurol 2009;66:54-59.

47 Held U, Heigenhauser L, Shang C, Kappos L, Polman C; Sylvia Lawry Centre for MS Research: Predictors of relapse rate in MS clinical trials. Neurology 2005;65:1769-1773.

48 West T, Wyatt M, High A, Bostrom A, Waubant E: Are initial demyelinating event recovery and time to second event under differential control? Neurology 2006;67:809-813.

49 Kelly MA, Cavan DA, Penny MA, Mijovic $\mathrm{CH}$, Jenkins D, Morrissey S, Miller DH, Barnett AH, Francis DA: The influence of HLA-DR and -DQ alleles on progression to multiple sclerosis following a clinically isolated syndrome. Hum Immunol 1993;37: 185-191.

50 Mowry EM, Carey RF, Blasco MR, Pelletier J, Duquette P, Villoslada P, Malikova I, Roger E, Kinkel RP, McDonald J, Bacchetti P, Waubant E: Multiple sclerosis susceptibility genes: associations with relapse severity and recovery. PLoS One 2013;8:e75416.

51 Kalincik T, Guttmann CR, Krasensky J, Vaneckova M, Lelkova P, Tyblova M, Seidl Z De Jager PL, Havrdova E, Horakova D: Multiple sclerosis susceptibility loci do not alter clinical and MRI outcomes in clinically isolated syndrome. Genes Immun 2013;14:244248.

52 Jensen CJ, Stankovich J, Van der Walt A, Bahlo M, Taylor BV, van der Mei IA, Foote SJ, Kilpatrick TJ, Johnson LJ, Wilkins E, Field J, Danoy P, Brown MA, Rubio JP, Butzkueven $\mathrm{H}$; Australian and New Zealand Multiple Sclerosis Genetics Consortium (ANZgene) Multiple sclerosis susceptibility-associated SNPs do not influence disease severity measures in a cohort of Australian MS patients. PLoS One 2010;5:e10003.

53 Lin R, Taylor BV, Simpson S Jr, Charlesworth J, Ponsonby AL, Pittas F, Dwyer T, van der Mei I: Association between multiple sclerosis risk-associated SNPs and relapse and disability - a prospective cohort study. Mult Scler 2014;20:313-321.

54 Masterman T, Ligers A, Olsson T, Andersson $\mathrm{M}$, Olerup O, Hillert J: HLA-DR15 is associated with lower age at onset in multiple sclerosis. Ann Neurol 2000;48:211-219.

55 Celius EG, Harbo HF, Egeland T, Vartdal F, Vandvik B, Spurkiand A: Sex and age at diagnosis are correlated with the HLA-DR2, DQ6 haplotype in multiple sclerosis. J Neurol Sci 2000;178:132-135.

56 Hensiek AE, Sawcer SJ, Feakes R, Deans J, Mander A, Akesson E, Roxburgh R, Coraddu F, Smith S, Compston DA: HLA-DR 15 is associated with female sex and younger age at diagnosis in multiple sclerosis. J Neurol Neurosurg Psychiatry 2002;72:184-187.

57 Weinshenker BG, Santrach P, Bissonet AS McDonnell SK, Schaid D, Moore SB, Rodriguez $\mathrm{M}$ : Major histocompatibility complex class II alleles and the course and outcome of
MS: a population-based study. Neurology 1998;51:742-747.

58 Pittas F, Ponsonby AL, van der Mei IA, Taylor BV, Blizzard L, Groom P, Ukoumunne OC Dwyer T: Smoking is associated with progressive disease course and increased progression in clinical disability in a prospective cohort of people with multiple sclerosis. J Neurol 2009; 256:577-585.

59 Kuhle J, Disanto G, Dobson R, Adiutori R, Bianchi L, Topping J, Bestwick J, Meier UC, Marta M, Costa GD, Runia T, Evdoshenko E, Lazareva $\mathrm{N}$, Thouvenot $\mathrm{E}$, Iaffaldano $\mathrm{P}$, Direnzo V, Khademi M, Piehl F, Comabella M, Sombekke M, Killestein J, Hegen $\mathrm{H}$, Rauch S, D'Alfonso S, Alvarez-Cermeño J, Kleinová $\mathrm{P}$, Horáková $\mathrm{D}$, Roesler R, Lauda F, Llufriu S, Avsar T, Uygunoglu U, Altintas A, Saip S, Menge T, Rajda C, Bergamaschi R, Moll N, Khalil M, Marignier R, Dujmovic I, Larsson H, Malmestrom C, Scarpini E, Fenoglio C, Wergeland S, Laroni A, Annibali V, Romano S, Martínez A, Carra A, Salvetti M Uccelli A, Torkildsen Ø, Myhr K, Galimberti D, Rejdak K, Lycke J, Frederiksen J, Drulovic J, Confavreux C, Brassat D, Enzinger C, Fuchs S, Bosca I, Pelletier J, Picard C, Colombo E, Franciotta D, Derfuss T, Lindberg R, Yaldizli Ö, Vécsei L, Kieseier B, Hartung H, Villoslada P, Siva A, Saiz A, Tumani H, Havrdova E, Villar L, Leone $\mathrm{M}$, Barizzone $\mathrm{N}$, Deisenhammer F, Teunissen C, Montalban $\mathrm{X}$, Tintoré $\mathrm{M}$, Olsson T, Trojano M, Lehmann S, Castelnovo G, Lapin S, Hintzen R, Kappos L, Furlan R, Martinelli V, Comi G, Ramagopalan S, Giovannoni G: Conversion from clinically isolated syndrome to multiple sclerosis: a large multicentre study. Mult Scler 2015;pii:1352458514568827.

60 Mohr DC, Hart SL, Julian L, Cox D, Pelletier D: Association between stressful life events and exacerbation in multiple sclerosis: a meta-analysis. BMJ 2004;328:731

61 Nisipeanu P, Korczyn AD: Psychological stress as risk factor for exacerbations in multiple sclerosis. Neurology 1993;43:13111312.

62 Golan D, Somer E, Dishon S, Cuzin-Disegni L, Miller A: Impact of exposure to war stress on exacerbations of multiple sclerosis. Ann Neurol 2008;64:143-148.

63 Kurland LT: Trauma and multiple sclerosis. Ann Neurol 1994;36(suppl):S33-S37.

64 Artemiadis AK, Anagnostouli MC, Alexopoulos EC: Stress as a risk factor for multiple sclerosis onset or relapse: a systematic review. Neuroepidemiology 2011;36:109120

65 Confavreux C, Suissa S, Saddier P, Bourdès V, Vukusic S; Vaccines in Multiple Sclerosis Study Group: Vaccinations and the risk of relapse in multiple sclerosis. Vaccines in multiple sclerosis study group. N Engl J Med 2001; 344:319-326

66 Mikaeloff Y, Caridade G, Assi S, Tardieu M, Suissa S; KIDSEP study group of the French Neuropaediatric Society: Hepatitis B vaccine and risk of relapse after a first childhood episode of CNS inflammatory demyelination. Brain 2007;130:1105-1110.

67 Bamford CR, Sibley WA, Laguna JF: Swine influenza vaccination in patients with multiple sclerosis. Arch Neurol 1978;35:242-243.

68 Myers LW, Ellison GW, Lucia M, Novom S, Holevoet M, Madden D, Sever J, Noble GR: Swine influenza virus vaccination in patients with multiple sclerosis. J Infect Dis 1977; 136(suppl):S546-S554.

69 Farez MF, Correale J: Yellow fever vaccination and increased relapse rate in travelers with multiple sclerosis. Arch Neurol 2011;68: 1267-1271.

70 Buljevac D, Flach HZ, Hop WC, Hijdra D, Laman JD, Savelkoul HF, van Der Meché FG, van Doorn PA, Hintzen RQ: Prospective study on the relationship between infections and multiple sclerosis exacerbations. Brain 2002;125:952-960.

71 Buljevac D, Verkooyen RP, Jacobs BC, Hop W, van der Zwaan LA, van Doorn PA, Hintzen RQ: Chlamydia pneumoniae and the risk for exacerbation in multiple sclerosis patients. Ann Neurol 2003;54:828-831.

72 Edwards S, Zvartau M, Clarke H, Irving W, Blumhardt LD: Clinical relapses and disease activity on magnetic resonance imaging associated with viral upper respiratory tract infections in multiple sclerosis. J Neurol Neurosurg Psychiatry 1998;64:736-741.

73 Tremlett $\mathrm{H}$, van der Mei IA, Pittas F, Blizzard L, Paley G, Mesaros D, Woodbaker R, Nunez M, Dwyer T, Taylor BV, Ponsonby AL: Monthly ambient sunlight, infections and relapse rates in multiple sclerosis. Neuroepidemiology 2008;31:271-279.

74 Sibley WA, Bamford CR, Clark K: Clinical viral infections and multiple sclerosis. Lancet 1985;1:1313-1315.

75 Andersen O, Lygner PE, Bergström T, Andersson M, Vahlne A: Viral infections trigger multiple sclerosis relapses: a prospective seroepidemiological study. J Neurol 1993;240: 417-422.

76 Millar JH, Allison RS, Cheeseman EA, Merrett JD: Pregnancy as a factor influencing relapse in disseminated sclerosis. Brain 1959;82: 417-426.

77 Confavreux C, Hutchinson M, Hours MM Cortinovis-Tourniaire P, Moreau T: Rate of pregnancy-related relapse in multiple sclerosis. Pregnancy in multiple sclerosis group. N Engl J Med 1998;339:285-291.

78 Vukusic S, Hutchinson M, Hours M, Moreau $\mathrm{T}$, Cortinovis-Tourniaire $\mathrm{P}$, Adeleine $\mathrm{P}$, Confavreux C; The Pregnancy In Multiple Sclerosis Group; Pregnancy In Multiple Sclerosis Group: Pregnancy and multiple sclerosis (the PRIMS study): clinical predictors of post-partum relapse. Brain 2004;127:13531360.

79 Nelson LM, Franklin GM, Jones MC: Risk of multiple sclerosis exacerbation during pregnancy and breast-feeding. JAMA 1988;259: 3441-3443. 
80 Salemi G, Callari G, Gammino M, Battaglieri F, Cammarata E, Cuccia G, D'Amelio M, Lupo I, Ragonese P, Savettieri G: The relapse rate of multiple sclerosis changes during pregnancy: a cohort study. Acta Neurol Scand 2004;110:23-26.

81 Hughes SE, Spelman T, Gray OM, Boz C, Trojano M, Lugaresi A, Izquierdo G, Duquette $P$, Girard M, Grand'Maison F, Grammond P, Oreja-Guevara C, Hupperts R, Bergamaschi R, Giuliani G, Lechner-Scott J, Barnett M, Edite Rio M, van Pesch V, Amato MP, Iuliano G, Slee M, Verheul F, Cristiano E, FernándezBolaños R, Poehlau D, Saladino ML, Deri N, Cabrera-Gomez J, Vella N, Herbert J, Skromne E, Savino A, Shaw C, Moore F, Vucic S, Petkovska-Boskova T, McDonnell G, Hawkins S, Kee F, Butzkueven H; MSBase study group: Predictors and dynamics of postpartum relapses in women with multiple sclerosis. Mult Scler 2014;20:739-746.

82 Korn-Lubetzki I, Kahana E, Cooper G, Abramsky O: Activity of multiple sclerosis during pregnancy and puerperium. Ann Neurol 1984;16:229-231.

83 Bernardi S, Grasso MG, Bertollini R, Orzi F, Fieschi C: The influence of pregnancy on relapses in multiple sclerosis: a cohort study. Acta Neurol Scand 1991;84:403-406.

84 Sadovnick AD, Eisen K, Hashimoto SA, Farquhar R, Yee IM, Hooge J, Kastrukoff L, Oger JJ, Paty DW: Pregnancy and multiple sclerosis. A prospective study. Arch Neurol 1994;51: 1120-1124.

85 Hellwig K, Haghikia A, Rockhoff M, Gold R: Multiple sclerosis and pregnancy: experience from a nationwide database in Germany. Ther Adv Neurol Disord 2012;5:247-253.

86 Portaccio E, Ghezzi A, Hakiki B, Sturchio A, Martinelli V, Moiola L, Patti F, Mancardi GL, Solaro C, Tola MR, Pozzilli C, De Giglio L, Totaro R, Lugaresi A, De Luca G, Paolicelli D, Marrosu MG, Comi G, Trojano M, Amato MP; MS Study Group of the Italian Neurological Society: Postpartum relapses increase the risk of disability progression in multiple sclerosis: the role of disease modifying drugs. J Neurol Neurosurg Psychiatry 2014;85:845-850.

87 Hellwig K, Haghikia A, Agne H, Beste C, Gold $\mathrm{R}$ : Protective effect of breastfeeding in postpartum relapse rate of mothers with multiple sclerosis. Arch Neurol 2009;66:1580-1581; author reply 1581 .

88 Langer-Gould A, Huang SM, Gupta R, Leimpeter AD, Greenwood E, Albers KB, Van Den Eeden SK, Nelson LM: Exclusive breastfeeding and the risk of postpartum relapses in women with multiple sclerosis. Arch Neurol 2009;66:958-963.

89 Portaccio E, Ghezzi A, Hakiki B, Martinelli V, Moiola L, Patti F, La Mantia L, Mancardi GL, Solaro C, Tola MR, Pozzilli C, De Giglio L, Totaro R, Lugaresi A, De Luca G, Paolicelli D, Marrosu MG, Comi G, Trojano M, Amato MP; MS Study Group of the Italian Neurological Society: Breastfeeding is not related to postpartum relapses in multiple sclerosis. Neurology 2011;77:145-150.
90 Michel L, Foucher Y, Vukusic S, Confavreux C, de Sèze J, Brassat D, Clanet M, Clavelou P, Ouallet JC, Brochet B, Pelletier J, Labauge P, Lebrun C, Lepage E, Le Frere F, JacqFoucher M, Barriere P, Wiertlewski S, Laplaud DA; Club Francophone de la Sclérose En Plaques (CFSEP): Increased risk of multiple sclerosis relapse after in vitro fertilisation. J Neurol Neurosurg Psychiatry 2012;83:796-802.

91 Laplaud DA, Leray E, Barrière P, Wiertlewski S, Moreau T: Increase in multiple sclerosis relapse rate following in vitro fertilization. Neurology 2006;66:1280-1281.

92 Hellwig K, Schimrigk S, Beste C, Muller T, Gold R: Increase in relapse rate during assisted reproduction technique in patients with multiple sclerosis. Eur Neurol 2009;61: 65-68.

93 Correale J, Farez MF, Ysrraelit MC: Increase in multiple sclerosis activity after assisted reproduction technology. Ann Neurol 2012; 72:682-694.

94 Oikonen M, Laaksonen M, Laippala P, Oksaranta O, Lilius EM, Lindgren S, RantioLehtimäki A, Anttinen A, Koski K, Erälinna JP: Ambient air quality and occurrence of multiple sclerosis relapse. Neuroepidemiology 2003;22:95-99.

95 Heydarpour P, Amini H, Khoshkish S, Seidkhani H, Sahraian MA, Yunesian M: Potential impact of air pollution on multiple sclerosis in Tehran, Iran. Neuroepidemiology 2014;43:233-238.

96 Miravalle A, Jensen R, Kinkel RP: Immune reconstitution inflammatory syndrome in patients with multiple sclerosis following cessation of natalizumab therapy. Arch Neurol 2011;68:186-191.

97 Havla J, Gerdes LA, Meinl I, Krumbholz M, Faber H, Weber F, Pellkofer HL, Hohlfeld $\mathrm{R}$, Kümpfel T: De-escalation from natalizumab in multiple sclerosis: recurrence of disease activity despite switching to glatiramer acetate. J Neurol 2011;258:16651669.

98 Cohen M, Maillart E, Tourbah A, De Sèze J, Vukusic S, Brassat D, Anne O, Wiertlewski S, Camu W, Courtois S, Ruet A, Debouverie M, Le Page E, Casez O, Heinzlef O, Stankoff B, Bourre B, Castelnovo G, Rico A, Berger E, Camdessanche JP, Defer G, Clavelou P, Al Khedr A, Zephir H, Fromont A, Papeix C, Brochet B, Pelletier J, Lebrun C; Club Francophone de la Sclérose en Plaques Investigators: Switching from natalizumab to fingolimod in multiple sclerosis: a French prospective study. JAMA Neurol 2014;71: 436-441.

99 Clerico M, Schiavetti I, De Mercanti SF, Piazza F, Gned D, Brescia Morra V, Lanzillo R, Ghezzi A, Bianchi A, Salemi G, Realmuto S, Sola P, Vitetta F, Cavalla P, Paolicelli D, Trojano M, Sormani MP, Durelli L: Treatment of relapsing-remitting multiple sclerosis after 24 doses of natalizumab: evidence from an Italian spontaneous, prospective, and ob- servational study (the TY-STOP study). JAMA Neurol 2014;71:954-960.

100 Rinaldi F, Seppi D, Calabrese M, Perini P, Gallo P: Switching therapy from natalizum$\mathrm{ab}$ to fingolimod in relapsing-remitting multiple sclerosis: clinical and magnetic resonance imaging findings. Mult Scler 2012; 18:1640-1643.

101 Jokubaitis VG, Li V, Kalincik T, Izquierdo G, Hodgkinson S, Alroughani R, LechnerScott J, Lugaresi A, Duquette P, Girard M, Barnett M, Grand'Maison F, Trojano M, Slee M, Giuliani G, Shaw C, Boz C, Spitaleri DL, Verheul F, Haartsen J, Liew D, Butzkueven H; MSBase Study Group: Fingolimod after natalizumab and the risk of short-term relapse. Neurology 2014;82: 1204-1211.

102 Cossburn M, Ingram G, Hirst C, Ben-Shlomo Y, Pickersgill TP, Robertson NP: Age at onset as a determinant of presenting phenotype and initial relapse recovery in multiple sclerosis. Mult Scler 2012;18:45-54.

103 Kalincik T, Buzzard K, Jokubaitis V, Trojano M, Izquierdo G, Duquette P, Girard M, Lugaresi A, Grammond P, Grand'Maison F, Oreja-Guevara C, Boz C, Hupperts R, Petersen $T$, Giuliani $G$, Iuliano $G$, LechnerScott J, Barnett M, Bergamaschi R, Van Pesch V, Amato MP, van Munster E, Fernandez-Bolanos R, Verheul F, Fiol M, Cristiano E, Slee M, Rio ME, Spitaleri D, Alroughani R, Gray O, Saladino ML, Flechter S, Herbert J, Cabrera-Gomez JA, Vella N, Paine M, Shaw C, Moore F, Vucic S, Savino A, Singhal B, Petkovska-Boskova T, Parratt J, Sirbu CA, Rozsa C, Liew D, Butzkueven $\mathrm{H}$ MSBase Study Group: Risk of relapse phenotype recurrence in multiple sclerosis. Mult Scler 2014;20:1511-1522.

104 Fay AJ, Mowry EM, Strober J, Waubant E: Relapse severity and recovery in early pediatric multiple sclerosis. Mult Scler 2012;18: 1008-1012.

105 Hirst CL, Ingram G, Pickersgill TP, Robertson NP: Temporal evolution of remission following multiple sclerosis relapse and predictors of outcome. Mult Scler 2012;18: 1152-1158.

106 Mowry EM, Pesic M, Grimes B, Deen S, Bacchetti P, Waubant E: Demyelinating events in early multiple sclerosis have inherent severity and recovery. Neurology 2009;72: 602-608.

107 Deen S, Bacchetti P, High A, Waubant E: Predictors of the location of multiple sclerosis relapse. J Neurol Neurosurg Psychiatry 2008;79:1190-1193.

108 Mowry EM, Deen S, Malikova I, Pelletier J, Bacchetti P, Waubant E: The onset location of multiple sclerosis predicts the location of subsequent relapses. J Neurol Neurosurg Psychiatry 2009;80:400-403.

109 Prineas JW, Barnard RO, Revesz T, Kwon EE, Sharer L, Cho ES: Multiple sclerosis. Pathology of recurrent lesions. Brain 1993;116: 681-693. 
110 Bramow S, Frischer JM, Lassmann H, KochHenriksen N, Lucchinetti CF, Sørensen PS, Laursen H: Demyelination versus remyelination in progressive multiple sclerosis. Brain 2010;133:2983-2998.

111 Mowry EM, Carey RF, Blasco MR, Pelletier J, Duquette P, Villoslada P, Malikova I, Roger E, Kinkel RP, McDonald J, Bacchetti P, Waubant E: Association of multiple sclerosis susceptibility variants and early attack location in the CNS. PLoS One 2013; 8:e75565.

112 Gourraud PA, Sdika M, Khankhanian P, Henry RG, Beheshtian A, Matthews PM, Hauser SL, Oksenberg JR, Pelletier D, Baranzini SE: A genome-wide association study of brain lesion distribution in multiple sclerosis. Brain 2013;136:1012-1024.

113 Greer JM, Csurhes PA, Muller DM, Pender MP: Correlation of blood $\mathrm{T}$ cell and antibody reactivity to myelin proteins with HLA type and lesion localization in multiple sclerosis. J Immunol 2008;180:6402-6410.

114 Hutchinson M: There is no such thing as a mild MS relapse. The mild relapse is an Anglo-Saxon delusion - commentary. Mult Scler 2012;18:930-931.

115 Confavreux C, Vukusic S, Moreau T, Adeleine $\mathrm{P}$ : Relapses and progression of disability in multiple sclerosis. N Engl J Med 2000; 343:1430-1438.

116 Hirst C, Ingram G, Pearson O, Pickersgill T, Scolding N, Robertson N: Contribution of relapses to disability in multiple sclerosis. J Neurol 2008;255:280-287.

117 Lublin FD, Baier M, Cutter G: Effect of relapses on development of residual deficit in multiple sclerosis. Neurology 2003;61:15281532.

118 Scalfari A, Neuhaus A, Degenhardt A, Rice GP, Muraro PA, Daumer M, Ebers GC: The natural history of multiple sclerosis: a geographically based study 10: relapses and long-term disability. Brain 2010;133:19141929.

119 Kalincik T, Vaneckova M, Tyblova M, Krasensky J, Seidl Z, Havrdova E, Horakova D: Volumetric MRI markers and predictors of disease activity in early multiple sclerosis: a longitudinal cohort study. PLoS One 2012; 7:e50101.

120 Confavreux C, Vukusic S, Adeleine P: Early clinical predictors and progression of irreversible disability in multiple sclerosis: an amnesic process. Brain 2003;126:770-782.

121 Leray E, Yaouanq J, Le Page E, Coustans M, Laplaud D, Oger J, Edan G: Evidence for a two-stage disability progression in multiple sclerosis. Brain 2010;133:1900-1913.

122 Tremlett H, Yousefi M, Devonshire V, Rieckmann P, Zhao Y; UBC Neurologists: Impact of multiple sclerosis relapses on progression diminishes with time. Neurology 2009;73:1616-1623.

123 Bergamaschi R, Berzuini C, Romani A, Cosi V: Predicting secondary progression in relapsing-remitting multiple sclerosis: a
Bayesian analysis. J Neurol Sci 2001;189: 13-21.

124 Simone IL, Carrara D, Tortorella C, Liguori M, Lepore V, Pellegrini F, Bellacosa A, Ceccarelli A, Pavone I, Livrea P: Course and prognosis in early-onset MS: comparison with adult-onset forms. Neurology 2002;59: 1922-1928.

125 Kantarci O, Siva A, Eraksoy M, Karabudak R, Sütlaş N, Ağaoğlu J, Turan F, Ozmenoğlu M, Toğrul E, Demirkiran M: Survival and predictors of disability in Turkish MS patients. Turkish multiple sclerosis study group (TUMSSG). Neurology 1998;51:765772.

126 Amato MP, Ponziani G, Bartolozzi ML, Siracusa G: A prospective study on the natural history of multiple sclerosis: clues to the conduct and interpretation of clinical trials. J Neurol Sci 1999;168:96-106.

127 Leone MA, Bonissoni S, Collimedaglia L, Tesser F, Calzoni S, Stecco A, Naldi P, Monaco F: Factors predicting incomplete recovery from relapses in multiple sclerosis: a prospective study. Mult Scler 2008;14:485493.

128 Riise T, Grønning M, Fernández O, Lauer K, Midgard R, Minderhoud JM, Nyland $\mathrm{H}$, Pálffy G, Poser S, Aarli JA: Early prognostic factors for disability in multiple sclerosis, a European multicenter study. Acta Neurol Scand 1992;85:212-218.

129 Langer-Gould A, Popat RA, Huang SM, Cobb K, Fontoura P, Gould MK, Nelson LM: Clinical and demographic predictors of long-term disability in patients with relapsing-remitting multiple sclerosis: a systematic review. Arch Neurol 2006;63:16861691.

130 Baghizadeh S, Sahraian MA, Beladimoghadam N: Clinical and demographic factors affecting disease severity in patients with multiple sclerosis. Iran J Neurol 2013;12:1-8.

131 Freund $\mathrm{P}$, Wheeler-Kingshott C, Jackson J, Miller D, Thompson A, Ciccarelli O: Recovery after spinal cord relapse in multiple sclerosis is predicted by radial diffusivity. Mult Scler 2010;16:1193-1202.

132 Mori F, Kusayanagi H, Nicoletti CG, Weiss S, Marciani MG, Centonze D: Cortical plasticity predicts recovery from relapse in multiple sclerosis. Mult Scler 2014;20:451457.

133 Bennetto L, Burrow J, Sakai H, Cobby J, Robertson NP, Scolding N: The relationship between relapse, impairment and disability in multiple sclerosis. Mult Scler 2011;17:12181224.

134 Miller DH, Chard DT, Ciccarelli O: Clinically isolated syndromes. Lancet Neurol 2012;11:157-169.

135 Barkhof F, Filippi M, Miller DH, Scheltens P, Campi A, Polman CH, Comi G, Adèr HJ, Losseff N, Valk J: Comparison of MRI criteria at first presentation to predict conversion to clinically definite multiple sclerosis. Brain 1997;120:2059-2069.
136 Tintoré M, Rovira A, Río J, Nos C, Grivé E Téllez N, Pelayo R, Comabella M, SastreGarriga J, Montalban X: Baseline MRI predicts future attacks and disability in clinically isolated syndromes. Neurology 2006; 67:968-972.

137 Fisniku LK, Brex PA, Altmann DR, Miszkiel KA, Benton CE, Lanyon R, Thompson AJ, Miller DH: Disability and T2 MRI lesions: a 20-year follow-up of patients with relapse onset of multiple sclerosis. Brain 2008;131: 808-817.

138 O'Riordan JI, Thompson AJ, Kingsley DP, MacManus DG, Kendall BE, Rudge P, McDonald WI, Miller DH: The prognostic value of brain MRI in clinically isolated syndromes of the CNS. A 10-year follow-up. Brain 1998;121:495-503.

139 Morrissey SP, Miller DH, Kendall BE, Kingsley DP, Kelly MA, Francis DA, MacManus DG, McDonald WI: The significance of brain magnetic resonance imaging abnormalities at presentation with clinically isolated syndromes suggestive of multiple sclerosis. A 5-year follow-up study. Brain 1993; 116:135-146.

140 Sombekke MH, Wattjes MP, Balk LJ, Nielsen $\mathrm{JM}$, Vrenken $\mathrm{H}$, Uitdehaag BM, Polman $\mathrm{CH}$ Barkhof F: Spinal cord lesions in patients with clinically isolated syndrome: a powerful tool in diagnosis and prognosis. Neurology 2013;80:69-75.

141 Tintore M, Rovira A, Arrambide G, Mitjana R, Río J, Auger C, Nos C, Edo MC, Castilló J, Horga A, Perez-Miralles F, Huerga E, Comabella M, Sastre-Garriga J, Montalban X: Brainstem lesions in clinically isolated syndromes. Neurology 2010; 75:1933-1938.

142 Di Filippo M, Anderson VM, Altmann DR Swanton JK, Plant GT, Thompson AJ, Miller $\mathrm{DH}$ : Brain atrophy and lesion load measures over 1 year relate to clinical status after 6 years in patients with clinically isolated syndromes. J Neurol Neurosurg Psychiatry 2010;81:204-208.

143 Fisher E, Lee JC, Nakamura K, Rudick RA Gray matter atrophy in multiple sclerosis: a longitudinal study. Ann Neurol 2008;64: 255-265.

144 Ferraro D, Simone AM, Bedin R, Galli V, Vitetta F, Federzoni L, D’Amico R, Merelli E, Nichelli PF, Sola P: Cerebrospinal fluid oligoclonal IgM bands predict early conversion to clinically definite multiple sclerosis in patients with clinically isolated syndrome. J Neuroimmunol 2013;257:76-81.

145 Jin YP, de Pedro-Cuesta J, Huang YH, Söderström M: Predicting multiple sclerosis at optic neuritis onset. Mult Scler 2003;9: 135-141.

146 Tintoré M, Rovira A, Río J, Tur C, Pelayo R, Nos C, Téllez N, Perkal H, Comabella M, Sastre-Garriga J, Montalban X: Do oligoclonal bands add information to MRI in first attacks of multiple sclerosis? Neurology 2008; $70: 1079-1083$ 
147 Miller DM, Weinstock-Guttman B, Béthoux F, Lee JC, Beck G, Block V, Durelli L, LaMantia L, Barnes D, Sellebjerg F, Rudick RA: A meta-analysis of methylprednisolone in recovery from multiple sclerosis exacerbations. Mult Scler 2000;6:267-273.

148 Beck RW, Cleary PA, Anderson MM Jr, Keltner JL, Shults WT, Kaufman DI, Buckley EG, Corbett JJ, Kupersmith MJ, Miller NR, et al: A randomized, controlled trial of corticosteroids in the treatment of acute optic neuritis. The optic neuritis study group. $\mathrm{N}$ Engl J Med 1992;326:581-588.

149 Sellebjerg F, Frederiksen JL, Nielsen PM, Olesen J: Double-blind, randomized, placebo-controlled study of oral, high-dose methylprednisolone in attacks of MS. Neurology 1998;51:529-534.

150 Barnes D, Hughes RA, Morris RW, WadeJones O, Brown P, Britton T, Francis DA, Perkin GD, Rudge P, Swash M, Katifi H, Farmer S, Frankel J: Randomised trial of oral and intravenous methylprednisolone in acute relapses of multiple sclerosis. Lancet 1997;349:902-906.

151 Martinelli V, Rocca MA, Annovazzi P, Pulizzi A, Rodegher M, Martinelli Boneschi F, Scotti R, Falini A, Sormani MP, Comi G, Filippi M: A short-term randomized MRI study of high-dose oral vs intravenous methylprednisolone in MS. Neurology 2009;73: 1842-1848.

152 Alam SM, Kyriakides T, Lawden M, Newman PK: Methylprednisolone in multiple sclerosis: a comparison of oral with intravenous therapy at equivalent high dose. J Neurol Neurosurg Psychiatry 1993;56:1219-1220.

153 Oliveri RL, Valentino P, Russo C, Sibilia G, Aguglia U, Bono F, Fera F, Gambardella A, Zappia M, Pardatscher K, Quattrone A: Randomized trial comparing two different high doses of methylprednisolone in MS: a clinical and MRI study. Neurology 1998;50: 1833-1836.

154 Manna SK, Aggarwal BB: Alpha-melanocyte-stimulating hormone inhibits the nuclear transcription factor NF-kappa B activation induced by various inflammatory agents. J Immunol 1998;161:2873-2880.

155 Ross AP, Ben-Zacharia A, Harris C, Smrtka J: Multiple sclerosis, relapses, and the mechanism of action of adrenocorticotropic hormone. Front Neurol 2013;4:21.

156 Abbruzzese G, Gandolfo C, Loeb C: 'Bolus' methylprednisolone versus ACTH in the treatment of multiple sclerosis. Ital J Neurol Sci 1983;4:169-172.

157 Barnes MP, Bateman DE, Cleland PG, Dick DJ, Walls TJ, Newman PK, Saunders M, Tilley PJ: Intravenous methylprednisolone for multiple sclerosis in relapse. J Neurol Neurosurg Psychiatry 1985;48:157-159.

158 Thompson AJ, Kennard C, Swash M, Summers B, Yuill GM, Shepherd DI, Roche S, Perkin GD, Loizou LA, Ferner R, et al: Relative efficacy of intravenous methylprednisolone and ACTH in the treatment of acute relapse in MS. Neurology 1989;39: 969-971.

159 Ramo-Tello C, Grau-López L, Tintoré M, Rovira A, Ramió i Torrenta L, Brieva L, Cano A, Carmona O, Saiz A, Torres F, Giner P, Nos C, Massuet A, Montalbán X, Martínez-Cáceres E, Costa J: A randomized clinical trial of oral versus intravenous methylprednisolone for relapse of MS. Mult Scler 2014;20:717-725.

160 Filippini G, Brusaferri F, Sibley WA, Citterio A, Ciucci G, Midgard R, Candelise L: Corticosteroids or ACTH for acute exacerbations in multiple sclerosis. Cochrane Database Syst Rev 2000;4:CD001331.

161 Elovaara I, Apostolski S, van Doorn P, Gilhus NE, Hietaharju A, Honkaniemi J, van Schaik IN, Scolding N, Soelberg Sørensen P, Udd B; EFNS: EFNS guidelines for the use of intravenous immunoglobulin in treatment of neurological diseases: EFNS task force on the use of intravenous immunoglobulin in treatment of neurological diseases. Eur J Neurol 2008;15:893-908.

162 Cortese I, Chaudhry V, So YT, Cantor F, Cornblath DR, Rae-Grant A: Evidencebased guideline update: plasmapheresis in neurologic disorders: report of the therapeutics and technology assessment subcommittee of the American academy of neurology. Neurology 2011;76:294-300.

163 Berkovich R: Treatment of acute relapses in multiple sclerosis. Neurotherapeutics 2013; 10:97-105.

164 Kappos L, Radue EW, O’Connor P, Polman C, Hohlfeld R, Calabresi P, Selmaj K, Agoropoulou C, Leyk M, Zhang-Auberson L, Burtin P; FREEDOMS Study Group: A placebocontrolled trial of oral fingolimod in relapsing multiple sclerosis. N Engl J Med 2010; 362:387-401.

165 Polman CH, O'Connor PW, Havrdova E, Hutchinson M, Kappos L, Miller DH, Phillips JT, Lublin FD, Giovannoni G, Wajgt A, Toal M, Lynn F, Panzara MA, Sandrock AW; AFFIRM Investigators: A randomized, placebo-controlled trial of natalizumab for relapsing multiple sclerosis. N Engl J Med 2006;354:899-910.

166 Coles AJ, Twyman CL, Arnold DL, Cohen JA, Confavreux C, Fox EJ, Hartung HP, Havrdova E, Selmaj KW, Weiner HL, Miller T, Fisher E, Sandbrink R, Lake SL, Margolin DH, Oyuela P, Panzara MA, Compston DA; CARE-MS II investigators: Alemtuzumab for patients with relapsing multiple sclerosis after disease-modifying therapy: a randomised controlled phase 3 trial. Lancet 2012;380:1829-1839.

167 He A, Spelman T, Jokubaitis V, Havrdova E, Horakova D, Trojano M, Lugaresi A, Izquierdo G, Grammond P, Duquette P, Girard M, Pucci E, Iuliano G, Alroughani R, OrejaGuevara C, Fernandez-Bolaños R, Grand' Maison F, Sola P, Spitaleri D, Granella F, Terzi M, Lechner-Scott J, Van Pesch V, Hupperts R, Sánchez-Menoyo JL, Hodgkin- son S, Rozsa C, Verheul F, Butzkueven H, Kalincik T; MSBase Study Group: Comparison of switch to fingolimod or interferon beta/glatiramer acetate in active multiple sclerosis. JAMA Neurol 2015;72:405-413.

168 Kalincik T, Horakova D, Spelman T, Jokubaitis $V$, Trojano $M$, Lugaresi A, Izquierdo G, Rozsa C, Grammond P, Alroughani R, Duquette P, Girard M, Pucci E, Lechner-Scott J, Slee M, Fernandez-Bolanos R, Grand'Maison F, Hupperts R, Verheul F, Hodgkinson S, OrejaGuevara C, Spitaleri D, Barnett M, Terzi M, Bergamaschi R, McCombe P, SanchezMenoyo J, Simo M, Csepany T, Rum G, Boz C, Havrdova E, Butzkueven H; MSBase Study Group: Switch to natalizumab versus fingolimod in active relapsing-remitting multiple sclerosis. Ann Neurol 2015;77:425-435.

169 Trojano M, Pellegrini F, Paolicelli D, Fuiani A, Zimatore GB, Tortorella C, Simone IL, Patti F, Ghezzi A, Zipoli V, Rossi P, Pozzilli C, Salemi G, Lugaresi A, Bergamaschi R, Millefiorini E, Clerico M, Lus G, Vianello M, Avolio C, Cavalla P, Lepore V, Livrea P, Comi G, Amato MP; Italian Multiple Sclerosis Database Network (MSDN) Group: Reallife impact of early interferon beta therapy in relapsing multiple sclerosis. Ann Neurol 2009;66:513-520.

170 Trojano M, Pellegrini F, Fuiani A, Paolicelli D, Zipoli V, Zimatore GB, Di Monte E, Portaccio E, Lepore V, Livrea P, Amato MP: New natural history of interferon-betatreated relapsing multiple sclerosis. Ann Neurol 2007;61:300-306.

171 Fahrbach K, Huelin R, Martin AL, Kim E, Dastani HB, Rao S, Malhotra M: Relating relapse and $\mathrm{t} 2$ lesion changes to disability progression in multiple sclerosis: a systematic literature review and regression analysis. BMC Neurol 2013;13:180.

172 Horakova D, Kalincik T, Dolezal O, Krasensky J, Vaneckova M, Seidl Z, Havrdova E: Early predictors of non-response to interferon in multiple sclerosis. Acta Neurol Scand 2012;126:390-397.

173 Rovaris M, Comi G, Ladkani D, Wolinsky JS, Filippi M; European/Canadian Glatiramer Acetate Study Group: Short-term correlations between clinical and MR imaging findings in relapsing-remitting multiple sclerosis. AJNR Am J Neuroradiol 2003;24: 75-81.

174 Sormani MP, Rovaris M, Comi G, Filippi M: A composite score to predict short-term disease activity in patients with relapsingremitting MS. Neurology 2007;69:12301235.

175 Burman J, Iacobaeus E, Svenningsson A, Lycke J, Gunnarsson M, Nilsson P, Vrethem M, Fredrikson S, Martin C, Sandstedt A, Uggla B, Lenhoff S, Johansson JE, Isaksson C, Hägglund H, Carlson K, Fagius J: Autologous haematopoietic stem cell transplantation for aggressive multiple sclerosis: the Swedish experience. J Neurol Neurosurg Psychiatry 2014;85:1116-1121. 
176 Burt RK, Loh Y, Cohen B, Stefoski D, Balabanov R, Katsamakis G, Oyama Y, Russell EJ, Stern J, Muraro P, Rose J, Testori A, Bucha J, Jovanovic B, Milanetti F, Storek J, Voltarelli JC, Burns WH: Autologous nonmyeloablative haemopoietic stem cell transplantation in relapsing-remitting multiple sclerosis: a phase I/II study. Lancet Neurol 2009;8:244-253.

177 Mancardi GL, Sormani MP, Di Gioia M, Vuolo L, Gualandi F, Amato MP, Capello E, Currò D, Uccelli A, Bertolotto A, Gasperini C, Lugaresi A, Merelli E, Meucci G, Motti L, Tola MR, Scarpini E, Repice AM, Massacesi L, Saccardi R; Italian BMT Study Group: Autologous haematopoietic stem cell transplantation with an intermediate intensity conditioning regimen in multiple sclerosis: the Italian multi-centre experience. Mult Scler 2012;18:835-842.

178 Ross AP, Halper J, Harris CJ: Assessing relapses and response to relapse treatment in patients with multiple sclerosis: a nursing perspective. Int J MS Care 2012;14:148-159.

179 Perrin Ross A, Williamson A, Smrtka J, Flemming Tracy T, Saunders C, Easterling C, Niewoehner J, Mutschler N: Assessing relapse in multiple sclerosis questionnaire: results of a pilot study. Mult Scler Int 2013; 2013:470476.

180 Oleen-Burkey M, Castelli-Haley J, Lage MJ, Johnson KP: Burden of a multiple sclerosis relapse: the patient's perspective. Patient 2012;5:57-69.

181 Healy BC, Degano IR, Schreck A, Rintell D, Weiner H, Chitnis T, Glanz BI: The impact of a recent relapse on patient-reported outcomes in subjects with multiple sclerosis. Qual Life Res 2012;21:1677-1684.

182 Nickerson M, Marrie RA: The multiple sclerosis relapse experience: patient-reported outcomes from the north American research committee on multiple sclerosis (NARCOMS) registry. BMC Neurol 2013;13:119.

183 Di Pauli F, Reindl M, Ehling R, Schautzer F, Gneiss C, Lutterotti A, O’Reilly E, Munger K, Deisenhammer F, Ascherio A, Berger T: Smoking is a risk factor for early conversion to clinically definite multiple sclerosis. Mult Scler 2008;14:1026-1030.

184 Brown RF, Tennant CC, Sharrock M, Hodgkinson S, Dunn SM, Pollard JD: Relationship between stress and relapse in multiple sclerosis: Part I. Important features. Mult Scler 2006;12:453-464.

185 Buljevac D, Hop WC, Reedeker W, Janssens AC, van der Meché FG, van Doorn PA, Hintzen RQ: Self reported stressful life events and exacerbations in multiple sclerosis: prospective study. BMJ 2003;327:646.

186 Oikonen M, Laaksonen M, Aalto V, Ilonen J, Salonen R, Erälinna JP, Panelius M, Salmi A: Temporal relationship between environmental influenza a and epstein-barr viral infections and high multiple sclerosis relapse occurrence. Mult Scler 2011;17:672680.
187 Roullet E, Verdier-Taillefer MH, Amarenco P, Gharbi G, Alperovitch A, Marteau R: Pregnancy and multiple sclerosis: a longitudinal study of 125 remittent patients. J Neurol Neurosurg Psychiatry 1993;56:10621065.

188 Giorgio A, Battaglini M, Rocca MA, De Leucio A, Absinta M, van Schijndel R, Rovira A, Tintoré M, Chard D, Ciccarelli O, Enzinger C, Gasperini C, Frederiksen J, Filippi M, Barkhof F, De Stefano N; MAGNIMS Study Group: Location of brain lesions predicts conversion of clinically isolated syndromes to multiple sclerosis. Neurology 2013;80: 234-241.

189 Ruet A, Arrambide G, Brochet B, Auger C, Simon E, Rovira A, Montalban X, Tintoré M: Early predictors of multiple sclerosis after a typical clinically isolated syndrome. Mult Scler 2014;20:1721-1726.

190 Mitjana R, Tintoré M, Rocca MA, Auger C, Barkhof F, Filippi M, Polman C, Fazekas F, Huerga E, Montalban X, Rovira A: Diagnostic value of brain chronic black holes on T1-weighted MR images in clinically isolated syndromes. Mult Scler 2014;20: 1471-1477.

191 Hartung HP, Freedman MS, Polman CH, Edan G, Kappos L, Miller DH, Montalbán X, Barkhof F, Petkau J, White R, Sahajpal V, Knappertz V, Beckmann K, Lanius V, Sandbrink R, Pohl C; BENEFIT Study Group: Interferon $\beta$-1b-neutralizing antibodies 5 years after clinically isolated syndrome. Neurology 2011;77:835-843.

192 Comi G, Martinelli V, Rodegher M, Moiola L, Leocani L, Bajenaru O, Carra A, Elovaara I, Fazekas F, Hartung HP, Hillert J, King J, Komoly S, Lubetzki C, Montalban X, Myhr KM, Preziosa P, Ravnborg M, Rieckmann P, Rocca MA, Wynn D, Young C, Filippi M: Effects of early treatment with glatiramer acetate in patients with clinically isolated syndrome. Mult Scler 2013;19:1074-1083.

193 Kinkel RP, Dontchev M, Kollman C, Skaramagas TT, O'Connor PW, Simon JH; Controlled High-Risk Avonex Multiple Sclerosis Prevention Study in Ongoing Neurological Surveillance Investigators: Association between immediate initiation of intramuscular interferon beta-1a at the time of a clinically isolated syndrome and long-term outcomes: a 10-year follow-up of the controlled high-risk avonex multiple sclerosis prevention study in ongoing neurological surveillance. Arch Neurol 2012;69:183190.

194 Miller AE, Wolinsky JS, Kappos L, Comi G, Freedman MS, Olsson TP, Bauer D, Benamor M, Truffinet P, O'Connor PW; TOPIC Study Group: Oral teriflunomide for patients with a first clinical episode suggestive of multiple sclerosis (TOPIC): a randomised, double-blind, placebo-controlled, phase 3 trial. Lancet Neurol 2014;13:977986.
195 Filippi M, Rovaris M, Inglese M, Barkhof F, De Stefano N, Smith S, Comi G: Interferon beta-1a for brain tissue loss in patients at presentation with syndromes suggestive of multiple sclerosis: a randomised, doubleblind, placebo-controlled trial. Lancet 2004; 364:1489-1496.

196 Runia TF, Jafari N, Siepman DA, Hintzen RQ: Fatigue at time of CIS is an independent predictor of a subsequent diagnosis of multiple sclerosis. J Neurol Neurosurg Psychiatry 2014;86:543-546.

197 Chard DT, Dalton CM, Swanton J, Fisniku LK, Miszkiel KA, Thompson AJ, Plant GT, Miller DH: MRI only conversion to multiple sclerosis following a clinically isolated syndrome. J Neurol Neurosurg Psychiatry 2011; 82:176-179.

198 Patrucco L, Rojas JI, Cristiano E: Assessing the value of spinal cord lesions in predicting development of multiple sclerosis in patients with clinically isolated syndromes. J Neurol 2012;259:1317-1320.

199 Rovaris M, Agosta F, Sormani MP, Inglese M, Martinelli V, Comi G, Filippi M: Conventional and magnetization transfer MRI predictors of clinical multiple sclerosis evolution: a medium-term follow-up study. Brain 2003;126:2323-2332.

200 Brex PA, Ciccarelli O, O’Riordan JI, Sailer M, Thompson AJ, Miller DH: A longitudinal study of abnormalities on MRI and disability from multiple sclerosis. N Engl J Med 2002;346:158-164.

201 Dalton CM, Chard DT, Davies GR, Miszkiel KA, Altmann DR, Fernando K, Plant GT, Thompson AJ, Miller DH: Early development of multiple sclerosis is associated with progressive grey matter atrophy in patients presenting with clinically isolated syndromes. Brain 2004;127:1101-1107.

202 Dalton CM, Brex PA, Jenkins R, Fox NC, Miszkiel KA, Crum WR, O'Riordan JI, Plant GT, Thompson AJ, Miller DH: Progressive ventricular enlargement in patients with clinically isolated syndromes is associated with the early development of multiple sclerosis. J Neurol Neurosurg Psychiatry 2002; 73:141-147.

203 Villar LM, Espiño M, Roldán E, Marín N, Costa-Frossard L, Muriel A, Alvarez-Cermeño JC: Increased peripheral blood CD5+ $B$ cells predict earlier conversion to MS in high-risk clinically isolated syndromes. Mult Scler 2011;17:690-694.

204 Liu Y, Duan Y, Yu C, Qin W, Chen H, Dong $\mathrm{H}$, Ye J, Butzkueven $\mathrm{H}, \mathrm{Li} \mathrm{K}$ : Clinical isolated syndrome: a 3-year follow-up study in China. Clin Neurol Neurosurg 2011;113:658660.

205 Magraner MJ, Bosca I, Simó-Castelló M, García-Martí G, Alberich-Bayarri A, Coret F, Alvarez-Cermeño JC, Martí-Bonmatí L, Villar LM, Casanova B: Brain atrophy and lesion load are related to CSF lipid-specific IgM oligoclonal bands in clinically isolated syndromes. Neuroradiology 2012;54:5-12. 